\title{
O pensamento estético e a Plástica de Herder
}

Pedro Augusto da Costa Franceschini - USP

"Justamente esta manhã eu estava lendo um de seus livros preferidos, a Plástica de Herder [...] tive prazer em me transportar em seu ser - certamente se trata, entre suas obras, daquela que lhe é mais própria [seineste], para me servir de uma expressão dele" (Schlegel, 1987, p. 12). Com essas palavras, Friedrich Schlegel escreve ao irmão August, no verão de 1791, falando sobre essa pequena obra de Herder, concluída em 1778. Schlegel não poupa críticas ao autor na sequência da carta, mas o que chama a atenção é como esse ensaio de Herder, certamente menos célebre que suas obras sobre a filosofia da linguagem e da história, poderia despertar um interesse mais profundo entre os futuros românticos, a ponto de contar entre as obras preferidas de August. Mais do que isso: como esse ensaio, aparentemente tão específico, limitado a uma teoria da escultura a partir do tato, poderia ser considerado a obra mais própria de Herder, alguém que, como se sabe, se aventurara em tantos âmbitos?

A expressão, como confessa Schlegel, aparece na própria Plás- 
tica: "a natureza formadora odeia abstrações: ela nunca dá tudo a uma única coisa, mas a cada coisa o que é seu e de seu jeito mais próprio" (Herder, 1994, p. 320). Ao defender na escultura, entendida como arte que dá forma, um procedimento análogo ao dessa natureza, Herder não apenas exige uma compreensão da especificidade dessa arte frente à pintura, mas constitui progressivamente em sua obra um novo ponto de vista para a estética, que se insira nessa concretude e nessa dinâmica orgânica entre o todo e a parte, universal e particular.

Que tal projeto exige, por um lado, um aprofundamento da estética na sensibilidade humana, é algo que revela a continuidade ao projeto herderiano traçado ao fim dos anos de 1760, sobretudo em sua Florestas críticas. De fato, escrito inicialmente entre os anos de 1768 e 1770, quando são redigidas três de suas cinco seções, esse ensaio de Herder empresta muito de sua Quarta floresta, mas também da Primeira: ao mesmo tempo em que aprofunda a análise psicológica da sensibilidade na constituição de nossos juízos, fazendo da estética uma verdadeira fisiologia dos sentidos, Herder também dá sequência ao plano de diferenciação sistemática das artes não apenas a partir dos meios e signos usados, mas através dos sentidos operantes em cada uma delas - da união dessas duas dimensões, por assim dizer da gnoseologia e da crítica de arte, vemos brotar uma teoria da escultura a partir do tato, que remete aos seus diálogos tanto com Baumgarten quanto com Lessing.

Por outro lado, líamos nessa mesma Quarta floresta que "todo o fundamento de nossa alma consiste em ideias obscuras" (Id., 1993, p. 273). Ora, ao defender no tato, justamente o nosso sentido mais lento e obscuro, não estaria Herder apontando, na experiência tátil com a escultura, para algo de mais primordial 
e essencial do que uma mera diferenciação entre belas artes? Nesse sentido, é preciso levar a sério os aportes trazidos pelas últimas seções, produtos de mais uma década de maturação do pensamento de Herder: progressivamente nos afastamos do quadro teórico das primeiras seções, para recuar a um ponto de vista mais originário, no qual, antes de uma teoria da sensibilidade em sentido estrito, aquém mesmo da divisão entre sujeito e objeto, a escultura é sentida novamente em sua forma viva. Restituindo-nos o ponto de vista do amante contemplador - e quem seria ele, senão Winckelmann? - Herder nos permitiria localizar na experiência deste autor um gesto fundador da própria estética alemã que se encontra aqui em constituição: o encontro com um elemento de ordem espiritual no mais profundo da intuição sensível.

Nesse mesmo movimento, observamos a intervenção de uma dimensão por assim dizer mitológica, que se coloca na mais íntima tensão com a teoria da sensibilidade que dá ensejo à obra: em que medida a sensibilidade é capaz de dar vida novamente à escultura, mas também depende de um substrato de formas vivas, um fundo poético-mitológico? Nessa tensão, através da qual oscila todo o ensaio de Herder, encontra-se a visada de amplitude histórica também fundamental na obra: como a escultura, enquanto forma inscrita historicamente, em seu apogeu ideal, na cultura grega, pode ser vivida por nós, modernos? Se não parece, de fato, haver uma resposta unívoca de Herder, a própria pergunta, no entanto, coloca em jogo elementos que nos permitem pensar na estética alemã, tal qual ela se consolida nas filosofias da arte do romantismo e do idealismo no fim do século XVIII.

Desse modo, mais do que uma breve apresentação da Plástica 
de Herder, gostaríamos de perscrutar esse seu aprofundamento e essas linhas de tensão, sugerindo em que medida, muito mais do que um livro particular e restrito na obra herderiana, a Plástica revelaria, efetivamente, ser-lhe muito própria. Para além de sua capacidade de concentrar problemas da teoria do conhecimento, da linguagem, da crítica e da história da arte, a obra mobilizaria tais pontos de vista na tentativa de articulá-los a partir de uma nova dimensão para a estética.

\section{$* * *$}

O início do texto de Herder não é de modo algum estranho ao cenário filosófico de meados do século XVIII, toma como ponto de partida o caso do cego de Puiseaux, da Carta sobre os cegos de Diderot, além de relatos do cego Saunderson e do cirurgião Cheselden. O autor se insere de maneira consciente em todo um debate do empirismo francês e inglês sobre a especificidade do sentido do tato em relação à visão, que remete à discussão entre Molyneux e Locke: um cego, tendo aprendido a reconhecer os objetos pelo tato, conseguiria identificá-los a partir de imagens, caso recuperasse a visão? Nesse sentido, o quadro teórico inicial se esboça sobretudo a partir de uma gnoseologia de método psicológico, de certo modo próximo ao ensaio publicado por Herder no mesmo ano em que a Plástica: Do conhecer e sentir na alma humana.

Do ponto de vista mais específico da estética, o quadro da discplina traçado por Baumgarten parecia ainda demasiadamente amplo e abstrato, colocando a necessidade de estudar os sentidos e refletir sobre os meios das diferentes artes. É no âmbito de um estudo mais aguçado da sensibilidade e de sua consequência na divisão das artes que os diferentes experimentos com a cegueira ganham relevância para o projeto herderiano. Nessa 
experiência de isolamento dos sentidos, Herder procura analiticamente diferenciar aquilo que em nossas impressões provém originariamente do tato, mas que o hábito nos leva a misturar com a visão. As lições recolhidas levam ao princípio de "que a visão apenas nos mostra figuras, o tato apenas corpos: que tudo o que é forma pode apenas ser reconhecido por meio do sentimento tátil e, por meio da visão, apenas superfícies e, na verdade, não corporais, e sim apenas superfícies de luz" (Ibid., p. 247).

Através de um vocabulário que explora o campo semântico da corporeidade, Herder chama a atenção para a solidez necessária para os fundamentos de nossos juízos, buscando nesse esquema uma valorização do tato, subjugado à primazia da visão na história da filosofia. Em sentido amplo, o autor sentira desde cedo a necessidade de um aprofudamento concreto da filosofia na experiência sensível, em oposição a uma tradição metafísica distante e abstrata, baseada no paradigma da visão; como indagava em seu diário: "O que fiz no passado para que eu esteja destinado a apenas ver sombras ao invés de sentir coisas reais? [...] $\mathrm{O}$ sentido do tato e o mundo do deleite - estes eu nunca desfrutei; eu vejo, sinto à distância [...]" (Id., 1997, p. 111-2). Em plena consonância com seu projeto estético de ancorar as operações intelectuais na sensibilidade humana, Herder lança mão, na Plástica, do jogo etimológico com a palavra alemã para conceito, Begriff, a partir do verbo greifen, segurar, agarrar, para explorar uma substancialidade originária e sensível fundamental naquilo mesmo que a filosofia julga mais seu. É a relação das coisas com nosso corpo que dão as suas propriedades, o "conceito da coisa", de modo que, "ao lado da sua razão", o homem possui "a mão abrangente e táctil" (Id., 1994, p. 249). 
Avançando nesse campo da teoria do conhecimento, Herder reconhece, todavia, que esse primeiro momento de especulação e diferenciação concerne ao estabelecimento de princípios a partir dos quais um empreendimento crítico possa circunscrever os domínios de cada uma das artes, reconduzindo-os à sua origem na sensibilidade. Aqui, mais uma vez, o predomínio da visão e o não aprofundamento na concreta dimensão sensível levou a divisões dedutivas e abstratas: se eu não penetro nesses conceitos dos outros sentidos, se não procuro a figura e a forma, em vez de ver, apreender originariamente, então eu pairo no ar eternamente com minha teoria do belo e do verdadeiro tirada da visão e nado com bolhas de sabão" (Ibid., p. 253). Nesse ponto, sintetizam-se tanto seu ataque a uma teoria do belo por demais abstrata, a qual via presente ainda em Baumgarten, mas também a crítica que segue sem se aprofundar na diferença dos sentidos, que imediatamente remete ao Laocoonte de Lessing. Mencionando a classificação das artes, geralmente feita a partir dos sentidos da visão e da audição, Herder repara que a noção de bela forma não se deixa determinar apenas pela visão. Da confusão entre a visão e o tato, "decorrem aquelas críticas lamentáveis, aquelas regras artísticas patéticas, proibitivas e estreitantes, aquela conversa agridoce acerca do belo universal" (Ibid., p. 256). Ora, desse ponto de vista universal não se dá conta da beleza da forma, o que o leva a concluir também que a visão não pode ser mãe da escultura. A partir desse esquema, que denomina seu "método subjetivo", ele estabelece uma nova divisão entre as artes: a música que lida com sons através da audição, a pintura que lida com superfícies através da visão, e a escultura com as formas, por meio do tato. ${ }^{1}$

${ }^{1}$ Sobre essa divisão, Jacqueline Lichtenstein afirma, no prefácio à edição 
É nesse sentido que se concretiza no ensaio a passagem para uma dimensão mais específica de cada arte e de sua manipulação própria dos signos. Herder se ocupa, então, com tópicos como a questão das vestimentas e do corpo nu na escultura, em torno da qual se desenvolve a problemática do panejamento, bem como a questão do uso da cor e da figuração do feio. O lema aqui é sobretudo evitar "fazer da necessidade de uma arte estranha a essência de sua própria arte e, assim, perder as vantagens do que é próprio" (Ibid., p. 265). Progressivamente, adentra na sua reflexão, todavia, um elemento de amplitude histórica: o foco na experiência sensível individual, na primeira parte, dá lugar a uma consideração mais ampla, de tal modo, por exemplo, que a questão da vestimenta traz à tona os costumes gregos. Nesse movimento, a oposição entre modernidade e a exemplaridade dos gregos, paradigmática na discussão estética de sua época, começa a brotar através do tratamento da escultura.

Por fim, essa problemática histórica torna-se uma questão que concerne à própria diferenciação entre as artes: em que medida as formas das esculturas são eternas e as figuras da pintura, "que são uma tela do tempo, mudam com a história, a espécie humana e os tempos" (Ibid., p. 276). Importante lembrar, no entanto, de acordo com a leitura historicista de Herder, que a

francesa da Plástica: "Se é verdade que ele [Herder] retoma para si uma oposição tradicional entre a pintura como arte da visão e a escultura como arte do toque, a qual encontramos em todos os escritos sobre a arte desde o Renascimento, sua análise, no entanto, não poderia ser considerada como uma variação suplementar de um exercício teórico já magistralmente praticado por Leonardo da Vinci, Roger de Piles, o abade Du Bos ou ainda Denis Diderot. Ele se apoia, com efeito, sobre argumentos filosóficos e não artísticos" (Herder, 2010a, p. II). Desse modo, não se trata de uma suposta originalidade na divisão das artes, mas da abordagem filosófica para o problema da escultura. 
escultura é suprema nos gregos não porque eles seguiam regras, mas porque nessa região "a bela formação regular é natureza" (Ibid., p. 277), ligada de forma necessária "ao espaço, o tempo, e o ócio" específicos desse povo, desse pedaço da terra ${ }^{2}$; nessa leitura, Herder tenta conciliar o caráter exemplar dos gregos com a sua leitura histórica, de modo que os monumentos dessa época "devem ser apenas amigos e não senhores; não devem subjugar,e sim, de acordo com o que diz o seu nome, ser modelo, representar corporalmente para nós a verdade de épocas antigas e indicarnos a concordância e o distanciamento entre suas formas de vida e as nossas". (Ibid., p. 277).

Essa importante passagem permite pensar a estratégia herderiana e notar certa virada que, a nosso ver, começa a operar de maneira mais clara nessa obra a partir do encerramento da segunda seção. Como observamos, o texto de Herder ensaia, por assim dizer, várias entradas para o problema da Plástica: primeiramente, uma discussão gnoseológica que procura situar a estética em um aprofundamento do método psicológico e do rastreamento da fruição artística a partir dos diferentes sentidos; ora, essa dimensão, digamos assim, "teórica", dá então lugar para

${ }^{2}$ A compreensão específica que faz Herder do conceito de natureza é seu principal recurso no embate com as interpretações classicistas normativas, célebre em seu ensaio Shakespeare, de 1773. Ao tomar a natureza como história, ligada a um desenvolvimento específico em cada época e lugar, as obras de arte, vistas como produções naturais, não podem mais ser concebidas como resultado de leis universais e atemporais que guiariam o fazer artístico. Isso vale de modo especial para os gregos: como afirma Szondi, "Herder pode dizer, aplicando a compreensão histórico genética contra a estética regulativa-classicista, que o artificial das regras não era nos gregos arte, mas natureza" (Szondi, 1974, p. 69). A Plástica se situa na tensão que se instaura entre essa leitura historicista, que concebe, portanto, as obras escultóricas gregas enquanto historicamente determinadas, e a tentativa de reviver tais formas a partir do tato e do sentimento. 
uma aplicação mais técnica, como que da ordem da crítica de arte, na qual as artes particulares, pintura e escultura, são tratadas com base em seus diferentes procedimentos, temas, meios e, inclusive, regras; a essa perspectiva, por sua vez, é adicionado um tratamento de amplitude histórica, no qual, por fim, o caráter exemplar dos gregos no domínio da escultura instaura uma dialética entre o moderno e o antigo. Parecendo sugerir que o verdadeiro ponto de vista estético não se esgota unicamente em nenhuma dessas abordagens, mas que exige certa assimilação e articulação dos mesmos, Herder aponta, portanto, para a escultura grega como modelo. Não nos parece, todavia, que o autor queira sugerir aí apenas um modelo para a atividade do escultor, no sentido de um simples guia para a prática artística. Herder emprega a noção de modelo, como ele mesmo indica "de acordo com o que diz o seu nome". Ora, o termo empregado, Vorbild, pode ser lido literalmente tanto como "uma imagem que está diante de nós", como também "uma imagem que é anterior", ou mesmo, levando ainda ao extremo, algo que está antes da própria imagem. Ao assumir a escultura como modelo, nesse duplo sentido, Herder parece procurar remeter a algo de presencial e primordial, que concerne a toda experiência estética, não apenas em oposição à pintura e à visão ${ }^{3}$.

\footnotetext{
${ }^{3}$ Essa é uma das passagens que revelam em que medida o ensaio de Herder cultiva relações profundas com o pensamento de Winckelmann, para além de Lessing e Baumgarten, já mencionados anteriormente. Não apenas seu objeto específico, a estatuária grega, mas sobretudo a confrontação histórica a partir daí, entre antiguidade e modernidade, revela um debate criativo com a obra do autor da História da arte da Antiguidade. Ao afirmar os gregos como modelo, Herder dialoga com a célebre formulação de Winckelmann: "o único meio de nos tornarmos grandes e, se possível, inimitáveis, é imitar os antigos" (Winckelmann, 1993, p. 39-40). Por um lado, ao aprofundar o sentido histórico que brotava no próprio Winckelmann, Herder vai contra
} 
Isso fica evidente quando, logo no início da terceira seção, o autor diz que "mesmo na pintura as formas das coisas têm de se tornar traços fundamentais, a substância da arte" (Ibid., p. 280). Ou seja, contrariando a tese de que se trata de um ensaio que procura meramente traçar linhas rígidas entre a escultura e a pintura, a partir do tato, Herder identifica nesse tipo de experiência, própria ao que chama de "a razão da mão" [ die Vernunft der Hand], algo que diz respeito mesmo à pintura, pois se trata daquilo que "dá as formas, os conceitos daquilo que elas significam e o que nelas habita" (Ibid., p. 280). Herder repetidamente procura traçar essa dependência, mesmo da pintura, a corpos, em um movimento que parece concernir à própria estética que não queira se tornar mera teoria abstrata: "todas as linhas de graça e beleza não são autônomas, mas dependem de corpos vivos; é destes que elas provem, e para eles que querem retornar" (Ibid., p. 281). Assim, parece ser a vida vivente, como a denomina Herder, que se encontra na base e faz surgir toda criação e fruição artísticas, as quais, simultânea e inversamente, dão

$\overline{\text { o postulado winckelmanniano }}$ da originalidade dos gregos, reivindicando, em sua Mais antiga floresta (1767), o imperativo de colocá-los em relação com outros povos, o que por fim escancara a aporia inerente ao pensamento winckelmanniano: a tensão entre a compreensão da especificidade históricogeográfica da arte grega e sua elevação a ideal supremo (Szondi, 1974, p. 24 e ss.). Por outro lado, não se pode esquecer que, próximo à época de publicação da Plástica, Herder escreve um necrológio em homenagem a Winckelmann, respondendo a um concurso lançado pela Academia de Antiguidades de Kassel em 1777, no qual percorre todas as obras do autor e revisa em grande parte o seu juízo ainda demasiadamente crítico do texto de 1767. A Plástica também pode ser lida nesse movimento de revisão que reconhece as grandes intuições de Winckelmann, inclusive reinterpretando em chave positiva a própria noção da arte grega como modelo, em uma compreensão de si mesma da modernidade e dos desafios assim colocados para a estética. 
também vida, como se nesse ponto de confluência a estátua só se tornasse propriamente estátua no momento em que a alma humana lhe dá vida, e o homem, inversamente, experimentasse novamente na estátua uma vida que lhe percorre.

Para reforçar esse ponto de vista específico que Herder parece exigir para e estética, cabe aqui lembrar a própria elasticidade no uso do termo Gefühl, para designar o sentido envolvido na apreciação das obras da escultura. Primeiramente entendido como o sentido estrito do tato, em passagens nas quais é colocado em oposição à visão, o termo constantemente designa certa operação feita pela visão na qual "tateia" com os olhos; mas em sentido ainda mais elementar, Herder parece utilizá-lo simplesmente como sentimento, uma receptividade fundamental, um estado de empatia originária do homem, enquanto ser sensível, que se instaura em uma relação anterior às divisões entre homem e mundo, sujeito e objeto, do mesmo modo que o tato se situa na imediatez entre aquele que toca e o que é tocado - como dirá Herder mais à frente: "simpatia interna, ou seja, tato e transferência de todo o nosso eu humano na figura tocada" (Ibid., p. 297) ${ }^{4}$. É nessa direção que a valorização herderiana do tato parece, por vezes, colocá-lo em uma "superi-

${ }^{4}$ Tal questão de vocabulário da sensibilidade, relacionado a um contato imediato e íntimo com o objeto, certamente não escapou aos românticos. August Schlegel, em sua Doutrina da Arte, fala justamente desse predomínio do vocabulário dos sentidos "baixos", como o gosto e o tato, para designar a fineza das operações artísticas e a receptividade humana em geral: "o sentimento [tato], o mais baixo de todos os sentidos, uma vez que parece ser meramente seu fundamento corporal, não é apenas empregado para o sentido artístico, mas também para a receptividade da mente a todas as manifestações nobres e éticas. Qual é, pois, a razão de não termos privilegiado junto a isso os assim chamados sentidos nobres, a audição e a visão? Provavelmente a clareza e a determinidade que tornam possíveis dedicar a esses sentidos artes próprias e belas os excluíram da eleição de 
oridade epistemológica", por assim dizer, em relação aos outros sentidos, principalmente à visão, quanto trata-se, na verdade, não propriamente de uma superioridade, mas de uma anterioridade fundamental. Com efeito, Herder já escrevia nos esboços para a Plástica:

O tato [Gefühl] é o primeiro, o mais profundo e quase o único sentido dos homens: a fonte da maior parte de nossos conceitos e sensações, o verdadeiro e primeiro orgão da alma a reunir representações de fora, o sentido que envolve inteiramente a alma, por assim dizer, e que contém em si os outros sentidos como tipos, partes ou abreviações; a medida de nossa sensibilidade, a verdadeira origem do verdadeiro, do bom, do belo! $(\text { Id., 1892, p. 104) })^{5}$.

um sentido universal para todas as artes. [...] No tato e na gustação, pelo contrário, somos conscientes de um contato imediato e justamente a intimidade e a obscuridade associada a esses sentidos parece ter-lhes dado aqui precedência. As produções da bela arte não devem ser um assunto do entendimento, mas estar numa relação mais própria com toda nossa essência. Devemos acolhê-las em nós. Isso ocorre, na verdade em um certo grau aos sentidos do tato, onde, por exemplo, o frio e o calor passam para nós, mas principalmente nos sentidos do gosto; segue-se aqui uma dissolução e fusão realmente químicas do objeto no órgão acolhedor e, desse modo, em toda nossa organização. Aqui reside, portanto, a semelhança com o sentido interno para o belo" (Schlegel, 2014, p. 44).

${ }^{5}$ Note-se que essa caráter unificador e de fundamento do Gefühl é também um momento da articulação de seu Ensaio sobre a origem da linguagem: "A todos os sentidos está subjacente o sentir físico [Allen Sinnen liegt Gefühl zum Grunde]. Ora, isso confere logo a todas as sensações um laço interno, tão forte e indizível, que dessa união resultam os fenômenos mais espantosos" (Herder, 1987, p. 83); o autor indaga mais à frente: "pois na sua origem, que outra coisa são os sentidos senão tato?" (Ibid., p. 86). Contra a hipótese da linguagem criada de forma inteiramente arbitrária e 
Tudo se passa como se o verdadeiro contato com a escultura grega possibilitasse a reconstrução desse momento original da sensibilidade humana o qual, para além de uma compreensão da fruição artística, apontaria para o próprio modo de ser do homem, na sua relação fundamentalmente imaginativa e poética com o mundo, indicando uma fundamentação da sensibilidade que vai muito além da sensibilidade em sentido estrito, ancorando de maneira radicalmente estética a existência humana, como sugeria a peculiar transformação herderiana do cogito cartesiano, presente também em seus esboços: "Eu me sinto! Eu sou! [Ich fülhe mich! Ich bin!]" (Ibid., p. 96).

Assim, o que Herder defende com a elevação do tato e da escultura a um novo patamar é uma experiência que escapa à estética dominada pelo entendimento e pela primazia da visão. Em oposição, o autor valoriza no tatear o fato de ser lento e obscuro, características negativas no âmbito da Schulphilosophie, que valorizava a claridade e a simultaneidade. Segundo Adler, "Herder inverte a hierarquia de valores. O ganho com o caráter obscuro do tato é a inteireza da representação e o ganho com a lentidão é o apuro" (Adler, 1990, p. 103). Nisso, coloca-se em jogo justamente aquilo que Baumgarten procurara validar com a estética, aquele conhecimento confuso das faculdades inferiores, de modo que a Plástica se insere de maneira relevante em seu diálogo

sem conteúdo, Herder acentua a raiz sensível do homem, como ser pensante que é "impressionado" por todos os lados, como um aspecto essencial para explicar o próprio surgimento da linguagem - os vários sentidos aparecem aqui como modos de representação de uma única força positiva (e poética) da alma. Logo, é possível observar que a Plástica, em sua insistência nessa originariedade do tato, na recepção e na produção artísticas, como atividade de dar forma ao mundo, retoma, em chave radicalmente concreta, algumas articulações e temas desse célebre ensaio de Herder, publicado em 1772 - o qual foi, portanto, concebido no longo período de gestação da Plástica. 
com a fundamentação desta disciplina. Em seu texto "Monumento a Baumgarten", Herder apontava que a grande intuição do autor da Estética fora aquela de que "na alma humana deve poder ser reconhecido e localizado com precisão um âmbito de propriedade da poesia", ou seja, "remontar a poética à sua mãe e amiga, a alma humana" (Id., 2010b, p. 60). Junto a esse mérito, no entanto, Herder não deixara de notar em vários momentos a tendência de Baumgarten a uma estética ainda demasiadamente abstrata e dedutiva, conduzida a priori, ao expressar seu pensamento a partir da armadura conceitual da filosofia wolffiana. Tal estética, nas palavras do próprio Herder, "pode ser o que quiser, mas o que o seu nome diz, ela não é: estética, uma teoria da sensibilidade" (Ibid., p. 65). Em contrapartida, a estética proposta por Herder "buscaria tudo nas profundezas de nossa sensibilidade, criaria a partir da sensação e extrairia do criado um espírito magnífico" (Ibid., p. 65). Tal aprofundamento da dimensão sensível da estética é identificado por Herder como a sua helenização: "que se desviem rios caudalosos da Grécia para purificar a nossa estética e torná-la frutífera" (Ibid., p. 64).

Ora, isso nos leva de volta ao caráter de modelo dos gregos no interior da Plástica. Ao conjugar a exigência de um aprofundamento sensível para a estética com uma consideração de amplitude histórica, Herder identifica a saída de uma estética dominada pelo entendimento e pela visão com uma filosofia da história da arte que identifica a escultura grega como um fenômeno historicamente determinado, no fundo, irreprodutível, mas que permite a possibilidade de um reencontro com a arte viva e com as exigências que se colocam para uma estética que procure assumir o homem vivo e total, considerado em todas suas faculdades. 
Parece ser assim, após várias entradas na questão, que Herder pode recuar a esse ponto de vista fundamental e encarar esse modelo, essa imagem presente e primordial: "Já falamos o bastante. Nós nos aproximamos de uma escultura como em uma escuridão sagrada, como se agora, pela primeira vez, nós devêssemos restituir-nos o mais simples conceito e significado da forma e, de fato, da mais nobre, mais bela e mais rica forma: aquele de um corpo humano". (Id., 1994, p. 282).

Fazendo uma analogia entre a criação divina do homem e a atividade de produção do escultor, Herder analisa cada uma das partes do corpo humano, em uma tipologia que em várias passagens lembra Winckelmann em sua História da arte da Antiguidade, realizada aqui do ponto de vista do escultor e da criação.

Assumindo o ideal de escultura winckelmanniano, da união entre bela natureza e beleza ideal, Herder repetidamente chama a atenção em seus exemplos para uma interioridade do corpo humano, ou melhor, para uma relação íntima entre interior e exterior que é assumida pelo escultor. Pode-se dizer que observamos na Plástica uma progressiva interiorização do problema da escultura, a qual coincide com a passagem de um ponto de vista de uma teoria da recepção para uma teoria da produção, de modo que a vitalidade assumida pela obra distancia-se de uma apreciação unicamente subjetiva, e abre-se para uma perspectiva mais objetiva e orgânica.

Uma característica dessa seção que não parece de modo algum desconexa desse deslocamento ao qual atentamos é a profusão de citações literárias: seja da Ilíada ou da Bíblia, das Metamorfoses de Ovídio ou do Hamlet de Shakespeare, cada parte do corpo é ilustrada por passagens, por assim dizer, "mitológicas". Assim, o paralelismo entre interior e exterior parece se dar, em 
última instância, a partir desse substrato poético comum: desse modo, não se fala dos cabelos, por exemplo, como uma categoria abstrata, mas dos cachos do Apolo que desce irado do cume do Olimpo, dos cabelos de Jesus como água e leite que fluem de seus ombros ou dos cabelos de Moisés como chamas de fogo. Não se deve, portanto, como afirma o próprio Herder mais à frente, confundir o procedimento desse capítulo com uma descrição erudita e livresca da Antiguidade: o recurso a certo conteúdo mitológico-bíblico reforça a presença no objeto, ou melhor, na forma viva, de algo divino e superior sem, no entanto, confundir esse conteúdo universal com algo da ordem abstrata.

Que o elemento mitológico intervenha nessa passagem é um testemunho mais uma vez que já nos encontramos muito distantes daquela que parecia a perspectiva inicial da Plástica, e que parece ser a leitura mais recorrente dos intérpretes, a saber, deste ensaio de Herder como uma mera aplicação de seu método analítico-psicológico ao caso específico da escultura através de uma análise do tato, ao qual se seguiriam trabalhos no campo da pintura e da música, por exemplo. É bem verdade que a origem da Plástica a partir da Quarta floresta, da qual empresta muitas passagens, aponta nessa direção e o próprio Herder parece já sugerir isso na folha de rosto do ensaio, onde se lê: "do início incompleto de tentativas análogas de uma anaglífica, ótica, acústica, etc" (Ibid., p. 244) $)^{6}$.

${ }^{6}$ De fato, tal projeto encontra-se delineado em sua Quarta floresta crítica. Ali, Herder concluía suas reflexões: "Examinamos os sentidos do que é belo para assinalar a cada um deles sua bela arte principal e, a partir da psicologia daquele, analisar a essência desta: nós chegamos então às próprias belas artes, para observar as ideias originais e características de sua natureza" (Herder, 1993, p. 372), ao que se segue o esboço de uma "estética do belo sentimento, uma filosofia da bela aparência, uma ciência estética 
Parece-nos, todavia, que o aprofundamento nessa estatuto primordial do tato, do próprio sentimento, como vimos, cria uma tensão no texto herderiano que abre uma nova perspectiva, a qual é completamente ignorada quando lemos o ensaio como mera continuidade do projeto da Quarta floresta e de uma teoria da sensibilidade em sentido estrito. Há, nesse sentido, novas intuições de Herder que são incorporadas às últimas seções da obra ao longo dos dez anos que separam a concepção e a publicação da Plástica. Se, por um lado, esse longo período de maturação cria um encadeamento aparentemente conflituoso entre as partes, de modo que as considerações finais parecem por vezes desvinculadas da base teórica construída no início do texto, não se deve ignorar a tensão e o aprofundamento da questão produzidos nesse movimento ${ }^{7}$. Assim, é imprescindível atentar para esse sutil deslocamento; de certa maneira, a entrada do elemento mitológico, completamente ausente nas primeiras seções, evidencia os limites de uma simples teoria da sensibilidade no projeto de "reanimar" a escultura. Em certo sentido, a própria referência ao mito de Pigmaleão, no subtítulo da obra ("Algumas percepções sobre a forma e a figura a partir do sonho formador de Pigmaleão"), coloca em jogo essa tensão pela qual se movimenta a obra e que diz respeito ao próprio estatudo da estética: se nos gregos é a própria mitologia que dá vida à

da música" (Ibid., p. 372). Um comentador como Norton, por exemplo, sugere que na Quarta floresta encontraríamos praticamente todo o esquema teórico da estética de Herder (Norton, 1991, p. 201-2)

${ }^{7}$ Como afirma Gaiger é daí que se vê surgir "uma tensão altamente produtiva que percorre toda a obra acabada" (Herder, 2002, p. 22). Por essa razão, é preciso discordar da afirmação de Norton em seu estudo de que "as seções finais da Plástica [...] baseiam-se essencialmente nas fundações teóricas dessa primeira parte e podem portanto ser puladas aqui" (Norton, 1991, p. 231). 
estátua, como uma moderna teoria da sensibilidade é capaz de vivificá-la novamente?

Como se sabe, nesse mito, narrado por Ovídio nas Metamorfoses, Pigmaleão se apaixona pela estátua na qual buscara atingir a beleza ideal. Com pena do escultor, Afrodite transforma a estátua em mulher, Galateia, com quem ele se casa. Não se deve ignorar a inspiração de Herder a partir desse mito, muito difundido no século XVIII como modelo para discutir uma superação sensualista do dualismo entre alma e corpo. Uma referência a ser pensada é certamente Condillac, que procura elucidar o problema da origem do conhecimento e da gênese das faculdades a partir da sensibilidade, no Tratado das sensações, por meio de um experimento que imagina uma estátua humana que ganha vida e cujos sentidos são progressivamente despertados. O mote da vivifação da estátua serve aí para "distinguir o que devemos a cada sentido" (Condillac, 1993, p. 34) - como vemos, algo muito próximo à teoria do conhecimento que embasa a Plástica, em uma reflexão psicológica que procura pensar, antes de tudo, o sujeito cognoscente a partir da sensibilidade. Por outro lado, não se pode esquecer também de Winckelmann, que fala do mesmo mito para pensar a atividade dos artistas gregos que "buscavam superar o duro objeto da matéria e, quando fosse possível, animá-la" (Winckelmann, 1934, p. 156). Nesse caso, o foco passa para a própria força que anima a estátua, quando algo de superior adentrar a matéria sensível.

Ora, é nessa passagem de uma dimensão subjetiva para outra objetiva que se dá o enunciado, contido na quarta seção da Plástica, de "que toda forma de sublimidade e beleza no corpo humano é e permanece sendo apenas a forma da saúde, da vida, da força e do bem-estar em cada membro dessa criatura plena 
de arte" (Herder, 1994, p. 296). Dando continuidade àquele aprofundamento na relação entre interior e exterior a partir da noção de forma viva, mas sem cair em algo abstrato, Herder afirma:

A boa figura do homem não é, portanto, uma abstração saída das nuvens, uma composição a partir de regras eruditas ou convenções arbitrárias; ela pode ser apreendida e sentida por qualquer um que sente, em si ou em outro, o que é a forma da vida, expressão da força, no vaso da humanidade. A beleza não é senão $o$ significado da perfeição interna [innerer Vollkommenheit]. (Ibid., p. 296)

Tal citação sintetiza o ataque de Herder a uma noção de beleza abstrata e normativa e também constitui uma abordagem objetiva para a estética por meio da noção de "perfeição interna". Nesse ponto, inclusive, é possível notar como Herder, ainda que tributário de uma estética amparada na psicologia e no princípio do efeito da obra sobre os sentidos, como fica evidente na abertura do ensaio, avança também em direções a novas formulações nas quais se pode vislumbrar algo do conceito de autonomia que marcará as estéticas do idealismo e do romantismo no fim do século XVIII ${ }^{8}$.

${ }^{8}$ Pensemos na possível aproximação com Moritz e com o conceito de "perfeito e acabado em si mesmo [in sich selbst Vollendetes]" (Moritz, 1997, p. 943), o qual, para Szondi, marca "uma libertação da arte das correntes da moral, uma libertação da estética das correntes da psicologia e uma inversão da relação de dependência, que significa a superação da estética do efeito e a fundação da estética real" (Szondi, 1974, p. 90). 
Desenvolvendo esse princípio interno, e unificando o que víamos anteriormente espalhado em vários membros do corpo, Herder situa junto à "forma da vida" a noção de uma "expressão da força". É assim que o autor coloca então, como diz, "as figuras humanas anteriores em ação" (Ibid., p. 296). O que vemos se desdobrar é uma teoria da expressão: se antes operavam as partes, aqui é a o todo que as anima: "imediatamente a beleza se torna força, significação em cada membro" (Ibid., p. 298). Há, desse maneira, uma relação orgânica entre as partes e o todo na forma viva, fazendo com que, na escultura, a expressão das partes deva se ligar à finalidade do todo. Uma deusa do amor sem graça, um Hércules sem força no corpo, por exemplo, aparecerão para nós como repugnantes, pois a beleza é "forma, expressão sensivel da perfeição para um fim", de modo que "quanto mais um membro significa o que ele deve significar, mais belo ele é" (Ibid., p. 297). A dinâmica orgânica entre parte e todo mostra-se aqui fundamental e anima outra relação essencial: "o que agora se aplica a caracteres e ações singulares tem de ser, em conjunto, verdadeiro de modo universal, pois todo universal é apenas no particular, e apenas a partir de todo particular é que surge o universal" (Ibid., p. 297). Tocando em uma questão central para toda a estética do século XVIII, a relação entre particular e universal ${ }^{9}$, Herder considera na escultura uma interpentração significativa dessas duas dimensões, as quais, articuladas na mitologia, dão a ela seu caráter determinado.

Nessa consideração da expressividade da forma da escultura,

${ }^{9}$ Em sentido amplo, segundo Baeumler, poder-se-ia dizer que se trata mesmo do problema da própria filosofia crítica, "que consistia em descobrir a relação que o particular, enquanto tal, mantém com o universal, sem no entanto deixá-lo subsistir em sua muda particularidade" (Baeumler, 1999, p. 86). 
tal determinidade é fruto da beleza como força poética ${ }^{10}$ que, movimentando os membros, faz com que eles então signifiquem um todo universal que dá a própria figura divina. Trata-se do mecanismo herderiano para se aproximar da beleza escultórica em chave concreta: "Ao invés do abstrato nas nuvens, que nenhum olho viu ou que nenhum ouvido escutou, essa beleza se torna concreta, mesmo nos deuses e deusas, ou seja, caráter de um deus e de nenhum outro" (Ibid., p. 298-9). Por essa razão, a figura do deus, mesmo entendido como algo da ordem universal, é sempre inseparável de sua expressão sensível e particular. É

10 Aqui, também, observa-se em que medida a noção de Gefühl não se limita ao tato em sentido estrito, mas a certa simpatia interna do homem sensível. As noções de força, espaço e tempo, relacionadas na Plástica aos corpos, superfícies e sons, respectivamente, são consideradas "os três maiores meios da criação oniabrangente, com os quais ela tudo apreende e envolve" (Herder, 1994, p. 257). Esses três conceitos, de fato, sempre foram para Herder os conceitos fundamentais da metafísica, elementares de nossa percepção do mundo, aos quais é possível reconduzir as ciências matemáticas e a partir dos quais procurava também desenvolver sua estética. Em sua divisão das artes deste ensaio, em escultura, pintura e música, o tato, enquanto sentido que apreende as partes uma na outra (a visão apreenderia uma ao lado da outra e a audição, uma depois da outra), é relacionado, como vimos, à percepção dos corpos, e portanto da força. Se recuarmos à Primeira floresta, no entanto, pintura e música continuam ligadas ao espaço e ao tempo, respectivamente, mas a força é então referida à poesia. Nesse contexto, a noção de força permitia a Herder diferenciar o lugar da poesia em relação às outras artes: apenas a caracterização da poesia como algo que atua por meio do tempo não dá conta de sua essência, pois todo discurso, enquanto tal, atua desse modo. A poesia, na realidade, age "por meio da força, que está presente nas palavras, por meio da força, que, embora passe através do ouvido, atua imediatamente sobre a alma" (Id., 1993, p. 194). Logo, tomando a ideia de força nesses dois contextos, é possível pensar, em um gesto de modo algum estranho aos românticos, como na Plástica, mais do que uma mera percepção tátil, trata-se de um aprofundamento da própria essência poética que permeia as artes, sendo que tatear a escultura é, no fundo, captar e doar a força poética que a anima. 
esse o caráter determinado da mitologia grega, justamente o que "ajudou os gregos a atingir um nível de arte que, desde então, não mais apareceu sobre a terra" (Ibid., p. 300). Relembrando o estatuto singular e único da arte grega, inscrito historicamente, Herder identifica essa exemplaridade dos gregos na capacidade de unir universal e particular na forma viva da escultura: só assim ela desperta em nós a "lira da simpatia humana", pois aí, na escultura, cada parte do corpo, sensível e particular, está em consonância com a alma, universal, restituindo em nós mesmos essa disposição originária, ou como diz Herder, quase transpondo "nossa alma para a mesma posição simpática" (Ibid., p. 301), na qual o intelectual e o sensível, o interior e o exterior, parecem se expressar mutuamente: "nós adquirimos um corpo, por assim dizer, com a natureza, ou ela adquire uma alma conosco" (Ibid., p. 301). Logo, o aprofundamento da noção da beleza como perfeição interna leva a uma visão na qual sujeito e objeto se fundem e a natureza é ela mesma sentida como animada, não abstratamente, ou mesmo "religiosamente", mas a partir da noção de forma - forma ideal humana compartilhada por homens e deuses: uma visão propriamente mitológica. ${ }^{11}$

11 Nessa relação entre universal e particular observamos também um pricípio de economia da expressão entre cada membro e o todo, de modo que "toda vez que uma forma, um membro deve significar de maneira proeminente, naturalmente ele vem à frente dos outros" (Herder, 1994, p. 297), assim por exemplo, no Apolo irado, "o nariz sopra um fôlego vivaz e abre espaço diante de si, o peito, uma bela armadura, arqueia-se de maneira nobre, as corajosas e longas coxas marcham. Os outros membros como que recuam humildemente, pois eles não estão na ação" (Ibid., p. 298). Essa economia, na qual certa prominência de algumas partes é compensada pela limitação de outras, dando assim o caráter determinado dos deuses, está de acordo com as considerações sobre a mitologia de Moritz, retomadas depois por Schelling: "o segredo do encanto [das figuras divinas] e sua aptidão para serem expostas artisticamente reside propriamente apenas nisto: antes de 
No entanto, como não podia deixar de ser em Herder, o pensamento de amplitude histórica coloca essa "essa atitude inteira" das estátuas gregas em perspectiva, perguntando-se o quanto estamos distantes dela. Esse caráter presencial, primordial e inteiro da escultura parece faltar ao moderno. Para apreender e conservar a unidade de um caráter humano, tal qual víamos na escultura, "a cara razão e a moral têm sempre de nos acudir, como a luz e a cor, pois tal figura não quer ficar em pé com os dois pés e se transforma como um fantasma" (Ibid., p. 301-2). Ao colocar em oposição à presencialidade e inteireza obscuras da plástica grega a moralidade e a racionalidade, a luz e a cor, próprias da pintura, notamos como aparece aí, na perspectiva moderna, certa ausência, dotada de claridade, mas que é ela mesma um fantasma.

De modo sintomático, a Plástica coloca em questão a própria possibilidade moderna de figuração: como, pode o artista, hoje, dar forma? O autor ironiza aqueles que querem reviver a Grécia como que pela "promulgação de éditos": um classicismo artificioso nada mais faz do que distribuir esculturas de aparência grega em praças e monumentos, sem que haja aquele sentimento que permitia que o grego se identificasse com a escultura e ela en-

mais nada, são rigorosamente delimitadas e, portanto, qualidades que se restringem reciprocamente, excluem-se e estão absolutamente separadas numa mesma deidade, e, não obstante, no interior dessa limitação cada forma recebe a divindade inteira" (Schelling, 2001, p. 55). Como afirma Suzuki ao comentar este trecho: "A graça de uma forma vem junto com uma certa ausência. Ou, reciprocamente, o que falta a um deus ou deusa é precisamente o que dá beleza, e também possibilidade de se armar um tecido coeso entre as diferentes figuras mitológicas" (Suzuki, 2005, p. 213). Na Plástica, percebemos o mesmo princípio aplicado à própria expressão da forma em movimento na escultura, permitindo traçar o pertencimento de Herder a uma linhagem de pensadores que assume certa visada "mitológica" para os problemas da estética. 
tão assumisse vida. Herder, no entanto, como o próprio ensaio testemunha, não julga tal sentimento perdido: ele parece viver na concretude da escultura, quando para ela nos voltamos com o sentimento verdadeiro. É nesse conflito, portanto, entre a ausência e uma presença que parece possível de ser revivida no tatear da escultura, no sentimento da plástica, que oscila e se desenvolve o ensaio de Herder.

A visão mitológica junta-se aqui à história: a escultura é vista a partir de sua origem mítica e seu desenvolvimento prosaico, por assim dizer, de modo que a história da arte tem de começar pelos próprios deuses, perdendo progressivamente esse seu princípio espiritual no desenvolvimento humano:

Do céu ela surgiu, veneração, amor, uma faísca dos deuses a trouxe para baixo, adquiriu sua forma terrena e por um tempo, ainda que bem curto, manteve-se viva. Então ela se tornou idolatria, em seguida arte, depois artesanato e, finalmente, a sopa onde tudo se mistura: assunto de conhecedores, tralha e tagarelice artística. (Ibid., p. 314).

É assim, que, para os povos selvagens, as estátuas eram habitadas por deuses, cheias de espírito e divindade, o que se explica também negativamente na interdição judaico-cristã à idolatria e na destruição das estátuas greco-romanas pelos nórdicos.

Nessa sintética história da arte, que se repete para Herder em todos os povos, situa-se, pois, a posição ambivalente do homem moderno: 
Ainda hoje somos tomados por um sentimento desse tipo em cada museu silencioso ou coliseu cheio de deuses e heróis: sem serem notados, quanto se está sozinho entre eles e deles se aproxima cheio de devoção, ele adquirem vida e por conta deles se é levado de volta ao tempo em que eles ainda viviam e tudo o que existe hoje como mitologia e estátua era verdade. (Ibid., p. 313)

Assim, a escultura é vista enquanto fenômeno historicamente determinado, distante, em sua origem mítica e viva. No entanto, nós mesmos podemos sentir isso novamente por meio de um outro aprofundamento no sentimento, que devolve à escultura a vida e que nos reenvia àquela plenitude. Como dissemos frequentemente, a Plástica parte de uma teoria da sensibilidade, mas parece progressivamente superá-la com a incorporação de novas perspectivas, que identificamos com a intervenção de um aporte, por assim dizer, mitológico, através do qual a vitalidade da escultura permeia o contemplador e o objeto em uma única forma viva. O desdobramento do peso da história, no entanto, coloca cada vez mais a distância em relação à antiguidade, constata a fragmentação moderna e faz com que retornemos àquela mesma sensibilidade, agora, todavia, reeducada nessa mitologia viva oferecida pela experiência da escultura.

A partir daí, é significativo que Herder conclua o ensaio se perguntando pela relação entre a alegoria e a arte da escultura, retomando um tema central da estética alemã de Winckelmann a Schlegel, Schelling e Hegel. Partindo da definição etimológica da alegoria como o um por meio do outro, o autor aponta que a arte da escultura é "uma alegoria consistente, pois ela figura a 
alma através do corpo [...].O artista tem em si mesmo o modelo do espírito, do caráter, da alma e cria para ele carne e ossos: ele alegoriza, portanto através de todos os membros" (Ibid., p. 319). Ao afirmar que na alegoria plástica encontram-se unificados esses dois outros mais extremos, alma e corpo, Herder sugere na própria escultura uma crítica à metafísica dualista, de modo que percebemos em que medida todo o movimento de fundamentação estética, que se coloca em oposição à poética tradicional, é ele mesmo um recurso crítico na exigência de um novo ponto de vista para a filosofia.

Herder, no entanto, aprofunda mais essa posição, de modo a problematizar a própria noção de alegoria. Se a defesa radical de uma concepção de forma viva na escultura interdita qualquer noção de uma transcendência intelectual abstrata e distante, de modo que sentimos "um sentido espiritual que mergulha aqui na pedra" (Ibid., p. 319), a própria noção de alegoria, ao menos em seu sentido usual, parece inapropriada para essa operação que está em jogo na escultura: "nós, que vivemos tão pouco no sentimento da plástica, demos à palavra alegoria exatamente o significado que não ocorre na plástica, mas em outras artes e ciências mais leves. E, no sentido estas, aquela sem dúvida não pode alegorizar"'(Ibid., p. 320). Ora, se na noção de alegoria recorrente o conteúdo sensível parece sempre exterior e reenviando à dimensão intelectual que lhe dá sentido, por meio de uma referência mediatizada, operada pelo entendimento, observamos que Herder claramente se distancia dessa noção quando defende a primazia do sentimento na experiência da escultura. A arte da escultura segue o mesmo procedimento da natureza formadora: " [ela] odeia abstrações: [...] nunca dá tudo a uma única coisa, mas a cada coisa o que é seu e de seu jeito mais 
próprio" (Ibid., p. 320). Não se trata portanto de abstrações, mas sempre de uma figura determinada, de um ponto de vista radicalmente concreto.

Logo, se começava falando da alegoria na escultura, uma compreensão mais pertinente logo revela que não é propriamente dela que se trata aí; a alegoria é reservada então a à gema, à moeda, à urna e ao baixo-relevo. Na escultura, na realidade, para usar do vocabulário de Herder ainda nos esboços para a Plástica, esse transluzir das forças da alma no corpo oferece uma verdadeira "simbólica" (Id., 1892, p. 106). Essa passagem de uma compreensão alegórica para uma compreensão, por assim dizer, simbólica oferece, portanto, um fechamento para o percurso do ensaio em direção à concretude da escultura. ${ }^{12}$ $* * *$

Para concluir, eu lembraria outras palavras de Friedrich Schlegel a respeito de Herder, agora em suas lições sobre a História da literatura antiga e moderna: "Poder-se-ia denominá-lo o mitólogo de nossa literatura, por conta desse sentido universal para a poesia, esse dom para experimentar as lendas antigas, para transportar-se simpaticamente em todas as figuras e produções da fantasia, o que exige por si só um elevado grau de fantasia"

\footnotetext{
12 É sobretudo com relação à mitologia, a qual vimos ser colocada no centro das preocupações do ensaio, que se pode falar em Herder da passagem de uma interpretação alegórica a outra simbólica. Como afirma Theisen: "Se o mito fosse alegórico, ele diria algo diferente do que diz, tentando apontar para uma verdade que a razão poderia representar de maneira mediada. O deslocamento paradigmático da noção de alegoria para a interpretação simbólica do mito foi instituída no contexto alemão, em larga medida, por Herder e sua historicização da literatura" (Theisen, 1998, p. 9). A partir do que vimos, é possível apreciar o aporte trazido pelo tratamento concreto da escultura no desenvolvimento herderiano em direção a uma interpretação simbólica.
} 
(Schlegel, 1961, p. 384). Se ligarmos essa consideração à nossa citação inicial, seria possível dizer que a Plástica é, de fato, exemplar na produção herderiana, ao conjugar a uma análise sobre a escultura esse "mitologismo", por assim dizer, característico de Herder, essa capacidade de transportar-se para outros tempos sentindo, tateando a força poética através do desenvolvimento de uma dimensão fundamentalmente simpática da alma humana.

Como vimos, algo mais essencial do que o mero esforço de diferenciar entre artes, sentidos e objetos ocorre aqui: ao identificar o tato com a simpatia interna, e ligá-lo à noção de poesia, Herder deixa claro que ressaltar a vida na escultura é ressaltar o que há aí de poético, de modo que não se trata apenas de como a imaginação se funde ao sentimento do tato, mas como essa experiência sensível mesma se faz linguagem: nesse sentido, o contemplador ideal, torna-se poeta, e a própria poesia pode, em certa medida, ser remetida a esse sentimento primordial e presencial. Nas palavras de Irmscher: "[Herder] não apenas descobre Winckelmann como poeta em suas descrições de esculturas, mas descobre também nelas a origem da poesia, por excelência, a partir da imaginação entusiasmada com o "tato"' (Irmscher, 1987, p. 73). Não se trata, obviamente, de limitar a poesia a essa sua origem no sentimento tátil, mas de um movimento de ir e vir do aparentemente mais material ao mais espiritual, até sua completa interpenetração na forma viva e concreta da escultura. Em última instância, esse aprofundamento no sentimento da plástica nos levaria a algo muito próximo daquele poetizar do qual falava August Schlegel:

Poetizar (tomado num sentido o mais amplo possível como o poético que está à base de todas as artes) nada mais é do 
que um eterno simbolizar: ora procuramos para algo espiritual um revestimento exterior, ora referimos um exterior ao interior invisível" (Schlegel, 2014, p. 93).

\section{Referências bibliográficas}

ADLER, H. Die Prägnanz des Dunklen. Hamburg: Felix Meiner Verlag, 1990.

BAEUMLER, A. Le problème de l'irrationalité dans l'esthétique et la logique du XVIIIème siècle; trad. Olivier Cossé. Strasbourg: Presses Universitaires de Strasbourg, 1999.

CONDILLAC, E. Tratado das sensações; trad. Denise Bottman. Campinas: Editora da UNICAMP, 1993.

HERDER, J. G. "Studien und Entwürfe zur Plastik". In: Sämmtliche Werke (in 32 Bänden); ed. Bernhard Suphan. Berlin: Weidmannsche Buchhandlung, 1892, vol. VIII.

___.. Ensaio sobre a origem da linguagem; trad. José M. Justo. Lisboa: Edições Ántigona, 1987.

.. Werke (in zehn Bänden); ed. Gunter E. Grimm. Frankfurt am Main: Deutscher Klassiker Verlag, 1993, vol. II.

.. Plastik. In: Werke (in zehn Bänden); ed. Jürgen Brummack e Martin Bollacher. Frankfurt am Main: Deutscher Klassiker Verlag, 1994, vol. IV.

.. Journal meiner Reise im Jahr 1769. In: Werke (in zehn Bänden); ed. Rainer Wisbert e Klaus Pradel. Frankfurt am Main: Deutscher Klassiker Verlag, 1997, vol. IX/2.

.. Sculpture; ed. e trad. de Jason Gaiger. Chicago: University of Chicago Press, 2002.

.. La Plastique; trad. e comentário de Pierre Pénisson, prefácio de Jacqueline Lichtenstein. Paris: Éditions du Cerf, 
2010a.

.. "Monumento a Baumgarten"; trad. e notas Oliver Tolle.

In: A palo seco, Ano 2, n.2, 2010b, pp. 58-65.

IRMSCHER, H. D. "Zur Ästhetik des jungen Herder". In: SAUDER,

G. (org) Johann Gottfried Herder: 1744-1803. Hamburg: Felix Meiner Verlag, 1987

MORITZ, K. p. Werke (in zwei Bänden); ed. Heide Hollmer e Albert Meier. Frankfurt am Main: Deutscher Klassiker Verlag, 1997.

NORTON, R. Herder's Aesthetics and the European Enlightenment. Ithaca; London: Cornell University Press, 1991.

SCHELLING, F. W. J. Filosofia da arte; trad., introd. e notas de Márcio Suzuki. São Paulo: Edusp, 2010.

SCHLEGEL, A. W. Doutrina da Arte: Cursos sobre Literatura Bela e Arte; introdução, trad. e notas Marco Aurélio Werle. São Paulos: Edusp, 2014.

SCHLEGEL, F. Kritische Friedrich-Schlegel-Ausgabe; ed. Hans Eichner. Paderborn: Verlag Ferdinand Schöningh, 1961, vol. VI.

.. Kritische Friedrich-Schlegel-Ausgabe; ed. Ernst Behler.

Paderborn: Verlag Ferdinand Schöningh, 1987, vol. XXIII. SUZUKI, M. "A ciência simbólica do mundo". In: NOVAES, A. (org.) Poetas que pensaram o mundo. São Paulo: Companhia das Letras, 2005, pp. 199-224.

SZONDI, p. Poetik und Geschichtsphilosophie I - Antike und Moderne in der Ästhetik der Goethezeit; Hegels Lehre von der Dichtung; ed. Senta Metz e Hans-Hagen Hildebrandt. Frankfurt am Main: Suhrkamp, 1974.

THEISEN, B. "Romantic myths of myth: myth as autopoiesis".

In: BELL, M.; POELLNER, p. (ed.) Myth and the making 
of modernity: The problem of grounding in early twentiethcentury literature. Amsterdam; Atlanta: Editions Rodopi B.V., 1998. pp. 9-23.

WINCKELMANN, J. Geschichte der Kunst des Altertums. Wien: Phaidon Verlag, 1934.

.. Reflexões sobre a arte antiga; trad. Herbert Caro e Leonardo Tochtrop. Porto Alegre: Movimento, 1993. 
